\title{
Detection of flavonoids in glandular trichomes of Chromolaena species (Eupatorieae, Asteraceae) by reversed-phase high-performance liquid chromatography
}

\author{
Silvia Helena Taleb-Contini ${ }^{1,2}$, Karin Schorr ${ }^{2,3}$, Fernando Batista Da Costa ${ }^{3}$, Dionéia Camilo \\ Rodrigues de Oliveira ${ }^{1^{*}}$
}

${ }^{1}$ Departamento de Física e Química, Faculdade de Ciências Farmacêuticas de Ribeirão Preto, Universidade de São Paulo, ${ }^{2}$ Departamento de Química, Faculdade de Filosofia, Ciências e Letras de Ribeirão Preto, ${ }^{3}$ Departamento de Ciências Farmacêuticas, Faculdade de Ciências Farmacêuticas de Ribeirão Preto, Universidade de São Paulo

*Correspondence:

D. C. R. Oliveira

Departamento de Física e Química

Faculdade de Ciências Farmacêuticas

de Ribeirão Preto

Universidade de São Paulo

Av. do Café $\mathrm{s} / \mathrm{n}^{\circ}$, Monte Alegre

14040-903 - Ribeirão Preto - SP, Brasil

E-mail: drolivei@fcfrp.usp.br
In this work, twelve flavonoids were detected in glandular trichomes of two species of Chromolaena through the glandular microsampling technique and HPLC-UV-DAD analysis. This is the first time that the accumulation of flavonoids in glandular trichomes of the genus Chromolaena is reported. Based on the results, we suggest that this technique can be an useful tool in the search of new compounds with medicinal properties as well as in chemotaxonomic studies of Eupatorieae.
Uniterms

- Asteraceae

- Chromolaena

- Eupatorieae

- Flavonoids

- Glandular trichomes

- HPLC-DAD

\section{INTRODUCTION}

Most plants, especially the angiosperms, biosynthesize and accumulate flavonoids induced by stress, like ultraviolet radiation, low temperatures, low amounts of nutrients, lack of water and pathogen attack (Úrzua, Andrade, 2001).

It is known that Asteraceae is among the principal families whose species accumulate secondary metabolites with a vast array of important biological activities. Depending on the ecosystem in which the plants grow, they can present glandular trichomes on the surface of the aerial parts, like flowers and leaves (Wollenweber, Dietz, 1981).

From the chemical point of view, the special ability of Asteraceae to produce and accumulate sesquiterpene lactones should be emphasized. Such compounds are generally accumulated in glandular trichomes of leaves or anther appendages and are related to plant defense against predators (Spring, 1999). The detection of chemical constituents stored in the glandular trichomes on leaves or anther appendages by HPLC allows the identification of several metabolites by means of indirect peak assignment using authentic reference compounds (Spring, 1991). For example, sesquiterpene lactones have been detected in glandular trichomes of many Heliantheae, thus contributing to chemotaxonomic studies concerning this tribe (Da Costa et al., 2001; Spring et al., 1999; Spring, 2000; Spring et al., 2003). Furthermore, other minor constituents from glands have also been reported, like a myoinositol derivative (Spring et al., 2001) as well as coumarins and flavonoids (Schorr et al., 2002).

So far, no efforts have been made with the aim to use the glandular trichome microsampling technique to characterize flavonoids in the glands of Eupatorieae species, although the identification of flavonoids is a valuable tool for chemotaxonomic studies of Asteraceae (Emerenciano et al., 2001), especially those from species 
which show low concentration or completely lack sesquiterpene lactones. Moreover, flavonoids present important biological activities (Modak et al., 2005).

The aim of the present study was to detect and characterize flavonoids accumulated in the glandular trichomes of two Eupatorieae species, Chromolaena hirsuta and C. squalida, using the glandular trichome microsampling technique.

\section{MATERIAL AND METHODS}

\section{Plant material}

Aerial parts from Chromolaena squalida (DC.) R. M. King \& H. Robinson and C. hirsuta (Hook. \& Arn.) R. M. King \& H. Robinson were collected by Prof. N. P. Lopes in Furnas, MG, Brazil, in April 1998, and identified by Prof. E. E. Schilling (Department of Botany, University of Tennessee, Knoxville, TN, USA) and H. Robinson (Department of Botany, Smithsonian Institution, Washington D.C., USA). Voucher specimens (NPL 126 and NPL 129 , respectively) are deposited at the Herbarium of the Department of Biology, FFCLRP/USP, under the codes SPFR 04412 and SPFR 04414, respectively.

\section{Detection of flavonoids in glandular trichomes}

Microscopic analysis of leaf surfaces of C. hirsuta and $C$. squalida revealed the presence of glandular trichomes. These trichomes were manually collected from the surface of entire air-dried leaves with a fine needle using a dissection microscope. For HPLC analysis, about 60 glandular trichomes of each plant were extracted with $40 \mu \mathrm{L}$ of $\mathrm{MeOH}$. The samples were extracted by stirring, during $10 \mathrm{~s}$. Following centrifugation $(10,000 \mathrm{rpm}$ for 20 s), the samples were filtered to remove insoluble parts, and an aliquot of each supernatant was injected and analysed by HPLC under the following isocratic conditions: $\mathrm{MeOH}-\mathrm{H}_{2} \mathrm{O} 3: 2,1.0 \mathrm{~mL} \mathrm{~min}{ }^{-1}$ (system 1), and $\mathrm{MeCN}-\mathrm{H}_{2} \mathrm{O}$ $35: 65,1.0 \mathrm{~mL} \mathrm{~min}{ }^{-1}$ (system 2 ), diode array detection (DAD), UV $\lambda_{\max } / \mathrm{nm} 250$ and $350 \mathrm{~nm}$, using DMP (2,5dimethylphenol) as reference compound $\left(10 \mathrm{~mol} \mathrm{~L}^{-1}\right)$, according to Da Costa et al. (2001). The run time was 20 min. Each peak was checked against previously isolated flavonoids using retention times relative to DMP $(r t=5.80 \mathrm{~min}$ in system 1 and $9.40 \mathrm{~min}$ in system 2$)$ in both solvent systems ( $r r t 1$ and $r r t 2$ - relative retention times to DMP in the systems 1 and 2, respectively) and by comparison of UV spectra obtained from DAD. For all compounds, the ratio of absorption between the wavelengths 250 and $350 \mathrm{~nm}\left(\mathrm{~A}_{250 / 350}\right)$ was also calculated.
It is an additional parameter to characterize a compound that is used together with the relative retention times in two solvent systems.

HPLC analyses were performed on a computerized Shimadzu SCL-10A VP liquid chromatograph operating with the software Class-VP (v. 5.02), a Macherey Nagel ODS column ( $4.6 \times 250 \mathrm{~mm}, 5 \mu \mathrm{m})$, and a Shimadzu SPDM10A VP DAD detector. Detection of flavonoids was performed using the same conditions described above and 15 compounds were used: quercetagetin 3,6,7-trimethyl ether (1), quercetin 3-O- $\alpha$-L-rhamnosyl-(1-6)- $\beta$-Dgalactoside (2), quercetin 3-O- $\alpha$-L-rhamnoside (3), luteolin (4), quercetin 3-methyl ether (5), quercetin (6), 6hydroxyluteolin-7-methyl ether (7), scutellarein 7-methyl ether (8), quercetagetin 3,6-dimethyl ether (9), luteolin 7,3'dimethyl ether (10), quercetagetin 3,6,3'-trimethyl ether (11), 6-methoxyluteolin (12), luteolin 6,3'-dimethyl ether (13), quercetagetin 3,6,7,3'-tetramethyl ether (14), and 6methoxyluteolin 7,3',4'-trimethyl ether (15) (Figure 1). All analyses were repeated three times. All compounds were obtained from previous investigations of $C$. hirsuta and $C$. squalida (Taleb-Contini et al., 2003, 2004) in which each species provided 14 and six flavonoids, respectively.
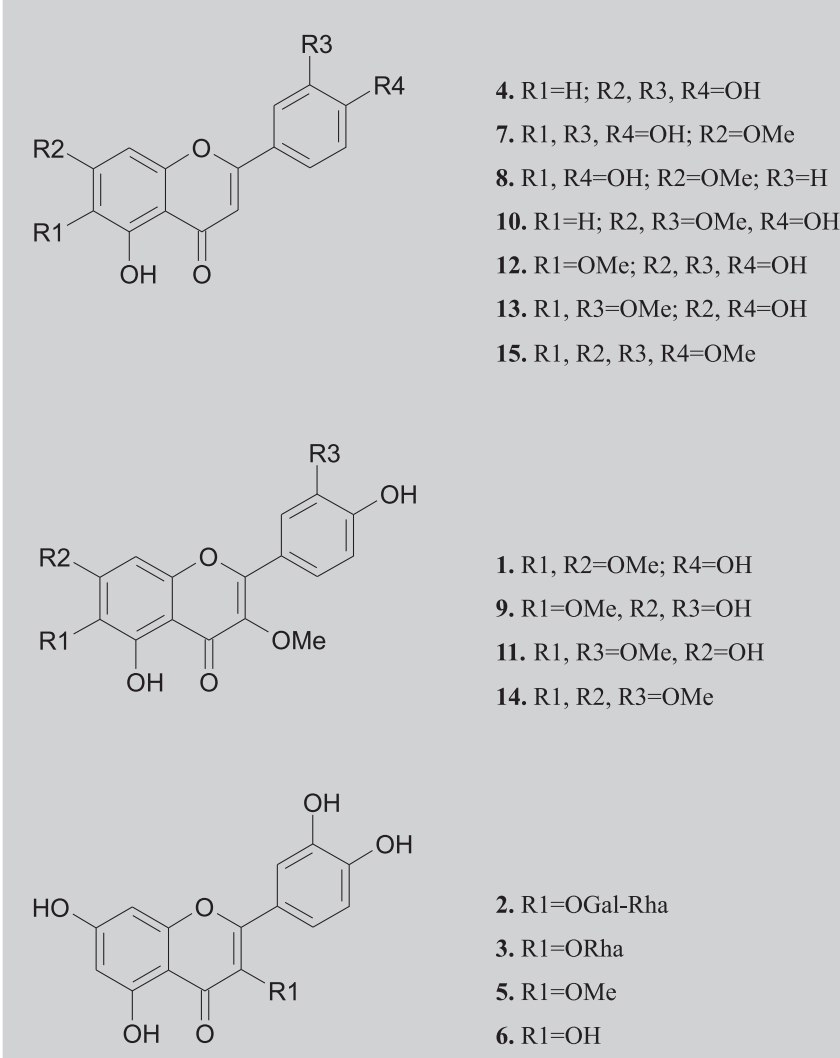
2. $\mathrm{R} 1=\mathrm{OGal}-\mathrm{Rh}$
3. $\mathrm{R} 1=\mathrm{ORha}$
5. $\mathrm{R} 1=\mathrm{OMe}$
6. $\mathrm{R} 1=\mathrm{OH}$

FIGURE 1 - Flavonoids from C. hirsuta and C. squalida used as reference compounds in the HPLC analysis. 


\section{RESULTS AND DISCUSSION}

This is the first report of flavonoids in foliar glandular trichomes of species from Eupatorieae. Both Chromolaena species presented mainly flavonol and flavone derivatives in their glands, including two glycosides (Figure 1). In this work, 12 of the 15 flavonoids originally reported in the crude extracts of the leaves of both species (Taleb-Contini et al., 2003, 2004) were characterized in their glandular trichomes (Table I), with the exception of compounds $\mathbf{7 , 9}$ and $\mathbf{1 4}$, which were not detected in any of them. In the previous study, the crude extracts of the leaves of $C$. hirsuta furnished 14 flavonoids (Table I) and now nine of them were found in the glandular trichomes (Table I, Figure 2). The crude extracts of $C$. squalida furnished earlier six flavonoids (Table I) and now six were detected in the glandular trichomes (Figure 3), but five of them are new to this species (Table I), being compound 2 the only that appeared in the glands and also in the crude extracts.

There are two main reasons to explain the discrepancies observed between the flavonoid content of the crude extracts and glandular trichomes. One reason is that the previously isolated compounds from the crude extracts, which were not detected in the glandular trichomes, might occur in other parts of the leaves, outside the trichomes. This hypothesis is supported by the work of Wollenwebber and Roitman (1996), in which the term "leaf exudate" was used to describe a leaf rinse extract of C. odorata prepared with an organic solvent. This exudate contains free aglycones and is assumed to be the normal accumulation site of such compounds in Asteraceae. The another reason is that the compounds that now appeared in the trichomes of each species but were not isolated earlier from their respective crude extracts were missed probably because the phytochemical procedures used during the extraction and isolation were not sensitive enough to allow their identification.

Another aspect to be discussed is that although fewer compounds were characterized in the glandular trichomes of both plants when compared to their respective crude extracts, it does not mean that the glands present low occurrence of such compounds. As can be observed in the chromatograms in Figures 2 and 3, both glandular contents are very rich, with at least 15 peaks each. Data from DAD analysis show that the great

TABLE I - Chromatographic data of the flavonoids used as reference compounds and their occurrence in the foliar glandular trichomes and crude extracts of C. hirsuta and C. squalida (Taleb-Contini et al., 2003, 2004)

\begin{tabular}{cccccccccc}
\hline Ref. compounds & rrt 1 & $r r t 2$ & $\mathrm{~A}_{250 / 350}$ & chd & CHE & gech & csd & cse & gecs \\
\hline $\mathbf{1}$ & 0.97 & 0.89 & 0.95 & nd & cd & nd & nd & nd & medium \\
$\mathbf{2}$ & 1.49 & 1.13 & 1.14 & nd & cd & nd & nd & cd & minor \\
$\mathbf{3}$ & 0.64 & 0.31 & 1.42 & $\mathrm{~cd}$ & nd & nd & nd & nd & major \\
$\mathbf{4}$ & 1.01 & 0.68 & 0.54 & nd & cd & minor & nd & nd & minor \\
$\mathbf{5}$ & 0.97 & 0.65 & 0.98 & cd & nd & minor & nd & nd & medium \\
$\mathbf{6}$ & 1.28 & 0.87 & 0.51 & nd & cd & minor & cd & cd & nd \\
$\mathbf{7}$ & 1.92 & 2.01 & 0.78 & nd & nd & nd & cd & nd & nd \\
$\mathbf{8}$ & 0.69 & 0.40 & 1.23 & cd & nd & minor & cd & nd & nd \\
$\mathbf{9}$ & 1.32 & 0.28 & 0.75 & cd & nd & nd & cd & cd & nd \\
$\mathbf{1 0}$ & 1.36 & 1.08 & 1.07 & cd & cd & minor & nd & nd & nd \\
$\mathbf{1 1}$ & 0.99 & 0.28 & 0.74 & cd & nd & major & nd & nd & nd \\
$\mathbf{1 2}$ & 1.17 & 0.71 & 0.82 & nd & cd & medium & nd & nd & minor \\
$\mathbf{1 3}$ & 1.39 & 1.16 & 0.94 & nd & cd & minor & nd & nd & nd \\
$\mathbf{1 4}$ & 1.99 & 2.08 & 0.79 & nd & cd & nd & cd & nd & nd \\
$\mathbf{1 5}$ & 0.97 & 0.60 & 0.85 & nd & cd & medium & nd & nd & nd \\
\hline
\end{tabular}

$r r t 1=$ relative retention time relative to DMP in the system $1\left(\mathrm{MeOH}: \mathrm{H}_{2} \mathrm{O}\right) ; r r t 2=$ relative retention time relative to DMP in the system $2\left(\mathrm{MeCN}: \mathrm{H}_{2} \mathrm{O}\right)$. Crude extracts: chd = dichloromethane extract of the leaves from $C$. hirsuta; che = ethanolic extract of the leaves from $C$. hirsuta; $\operatorname{csd}=$ dichloromethane extract of the leaves from $C$. squalida; $\operatorname{cse}=$ ethanolic extract of the leaves from C. squalida; Glandular trichome extracts: gecs $C$. squalida = glandular extract from leaves of C. squalida; gech C. hirsuta $=$ glandular extract from leaves of $C$. hirsuta; $\mathrm{cd}=$ compound isolated from crude extract; major $=$ major peak; medium = medium peak; minor = minor peak; nd $=$ not detected; reference compounds $=$ see Figure 1. 


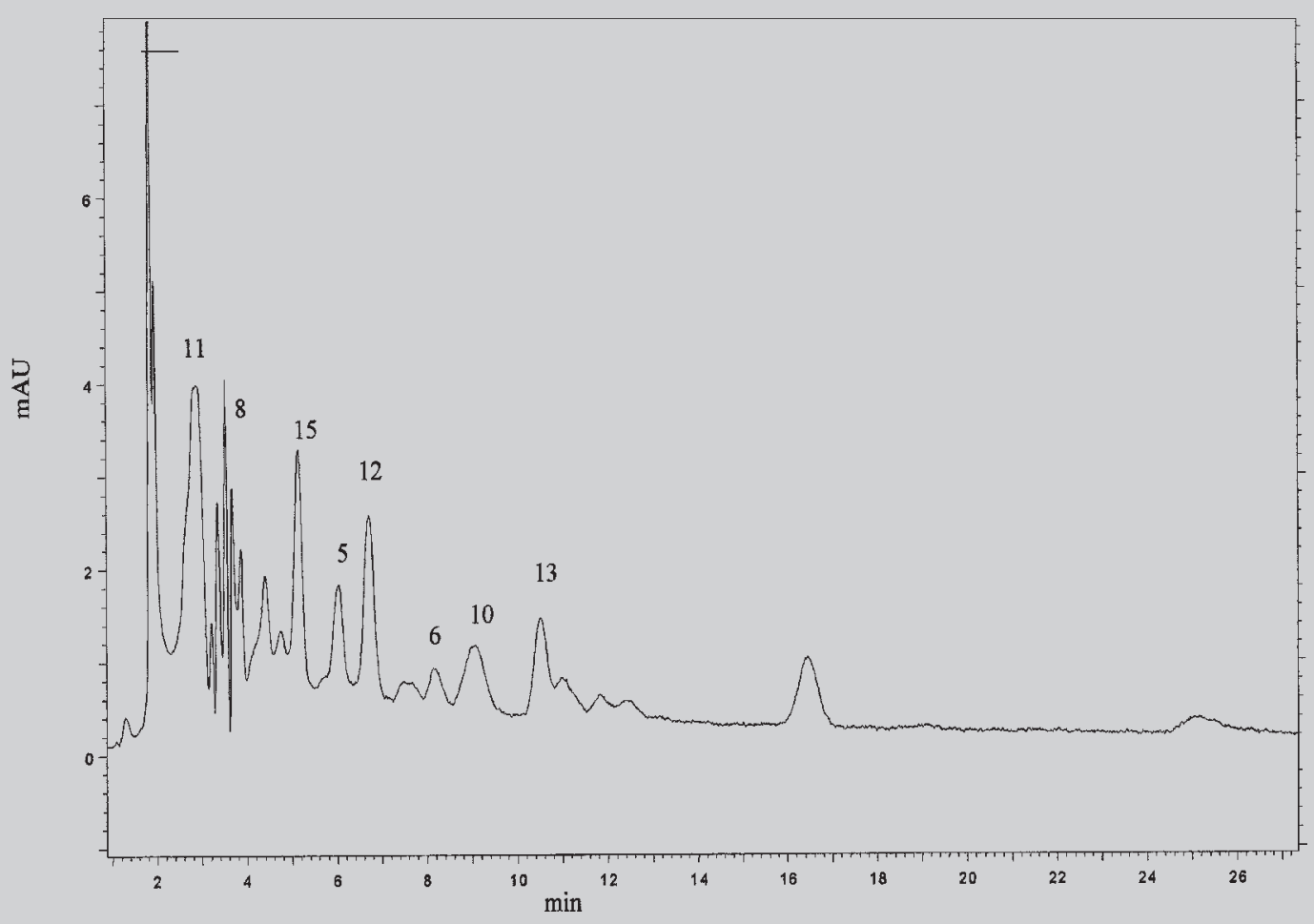

FIGURE 2 - HPLC Chromatogram of glandular trichome extracts of C. hirsuta. Column: Macherey Nagel ODS (4.6 x $250 \mathrm{~mm}$, $5 \mu \mathrm{m}$; eluent: $\mathrm{MeCN}: \mathrm{H}_{2} \mathrm{O}$ 65:35; flow-rate: $1 \mathrm{~mL} \mathrm{~min}^{-1}$; reference compound: DMP ( $\left.r t=9.40 \mathrm{~min}\right)$; detection: $250 \mathrm{~nm}$.

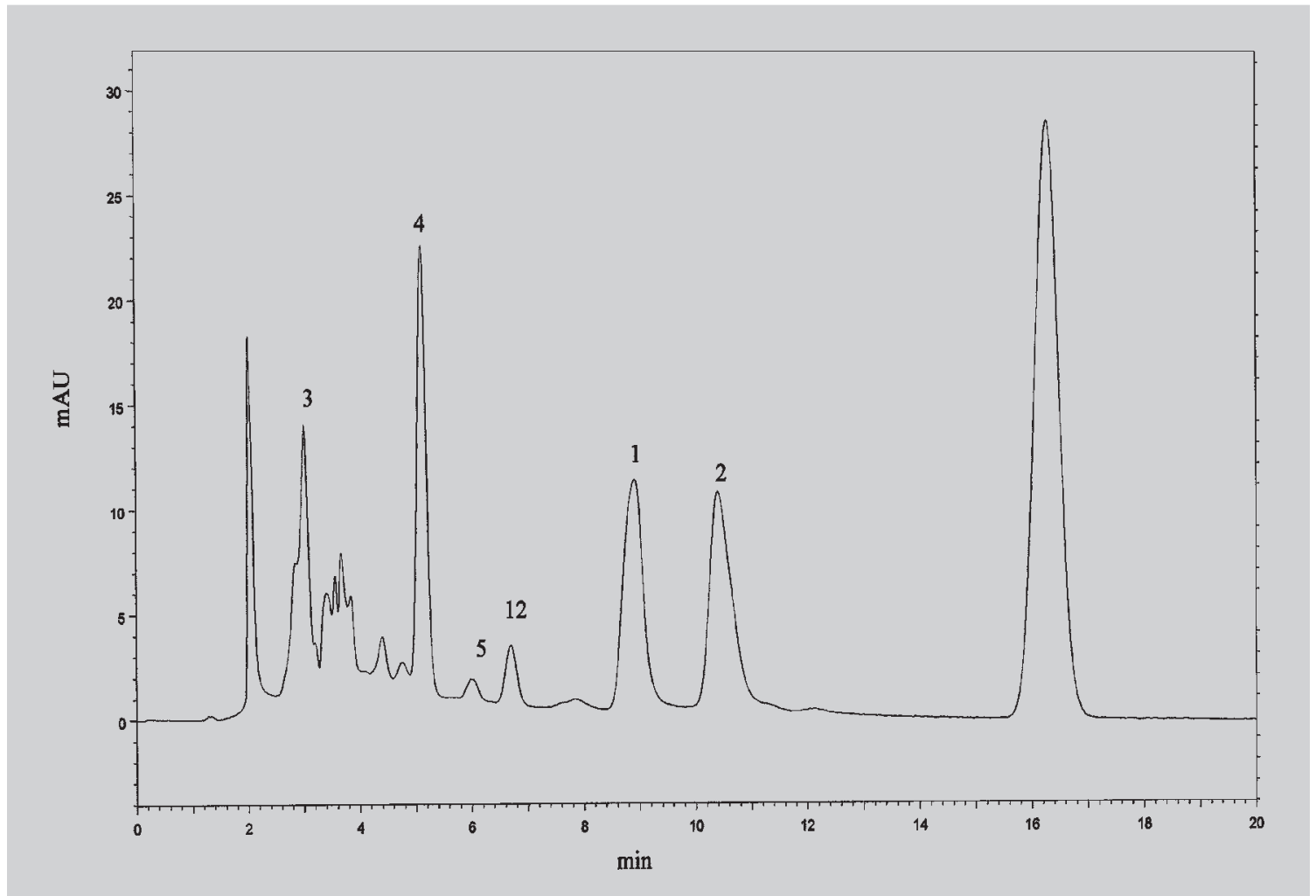

FIGURE 3 - HPLC Chromatogram of glandular trichome extracts of C. squalida. Column: Macherey Nagel ODS (4.6 x $250 \mathrm{~mm}, 5 \mu \mathrm{m}$; eluent: $\mathrm{MeCN}: \mathrm{H}_{2} \mathrm{O}$ 65:35; flow-rate: $1 \mathrm{~mL} \mathrm{~min}^{-1}$; reference compound: DMP ( $r t=9.40$ min); detection: $250 \mathrm{~nm}$. 
majority of these peaks correspond to aromatic compounds. In summary, our results indicate that several flavonoids are located in the foliar glandular trichomes of the two investigated Chromolaena species and that the proposed methodology is useful to characterize such compounds in a fast, reliable and easy way when compared to classical phytochemical methods. Even if leaf exudates are investigated, it is hard to know if a certain compound is from the trichome or somewhere else on the leaf. In our study, if the substitution patterns of these compounds are taken into account for each species, it can be observed that the compounds detected in the glands show the same type of substitution as those from the crude extract which were not detected in the glands, i.e., the compounds show double bonds between C-2 and C-3, catechols at C-3'/C-4', -OR substituents at C-3 (or its related flavones), or -OR at C-6. Thus, when the glandular trichomes extract is used for HPLC fingerprints, the chemical profile of the entire leaf is preserved.

Although the glandular trichomes of $C$. hirsuta and C. squalida share flavonoids with similar general substitutional features (Table 1), the results show qualitative and semi-quantitative differences between them. In the exudates of C. hirsuta, $\mathbf{1 1}$ is the main compound, followed by $\mathbf{1 2}$ and $\mathbf{1 5}$. However, $\mathbf{1 1}$ is absent in C. squalida, while its main metabolite is $\mathbf{3}$, followed by $\mathbf{1}$ and $\mathbf{5}$.

The leaf exudate of $C$. odorata, a previously investigated species from the Guam island in the Pacific (Wollenwebber and Roitman, 1996), showed mainly flavanones and 4'- $O$-methyl ether derivatives of 3',4'-di$O$-substituted flavonols instead of the corresponding 4'- $O$ hydroxy derivatives of 3',4'-di-O-substituted flavonols, which were found in the Brazilian species investigated in this work. Moreover, other minor flavonoids, like flavanones, chalcones, and a dihydroflavonol were isolated as minor compounds from $C$. odorata. In contrast, the Brazilian species completely lack such constituents but showed two 3-O-glucoside derivatives.

It was earlier shown that in order to characterize the metabolites in the glands, it is necessary to have a library of previously identified compounds (Spring, 1991). The HPLC technique used herein is quite simple but when it is associated to the collection of glands from specific structures of plants as well as to a pure compound library, it becomes a powerful tool for rapid and non-destructive analysis of plant material prior to classical phytochemical studies. The results of this work reinforce the previous statements based on the analysis of sesquiterpene lactones.
Carvalho et al. (1991) have described in vivo antimalarial activity of $C$. squalida (E. squalidum) against the parasite Plasmodium berghei. It is important to stress that flavonoids exhibit antioxidant, anti-inflammatory, antimicrobial, vascular activities and other medicinal properties (Xu, Lee, 2001; Ogundipe et al., 2001). Antimicrobial, antiprotozoal and antioxidant activities were observed for the flavonoids of $C$. hirsuta and $C$. squalida (Taleb-Contini et al., 2003; Taleb-Contini et al., 2004; Taleb-Contini et al., 2006).

In the present work, some of these biologically active flavonoids could be detected in the glandular trichomes of both Chromolaena species, which is a very interesting aspect of the chemistry of Asteraceae. Spring (1991) stated that the glandular trichomes also store flavonoids or even other antioxidant compounds and that they are probably responsible for the chemical protection of the sesquiterpene lactones inside these structures.

Sesquiterpene lactones could be easily degraded by oxidation or light, but inside the glandular trichomes, due to the fact that these compounds are produced at the early stages of plant developing and since the aerial parts receive the first sun radiation, they remain unaltered for the entire life of the plant (Da Costa et al., 2001). The detection of flavonoids in these structures corroborates this statement. On the other hand, it is also known that flavonoids are maybe produced in different parts of the plants, the so-called leaf exudates. That is the reason why it was not possible to detect all of them in the glandular trichomes.

\section{CONCLUSIONS}

Considering the great number of flavonoids identified in the course of chemical investigations of many Eupatorieae (Herz, 2001), their high chemotaxonomic value (Emerenciano et al., 2001) as well as the vast array of biological activities presented by this class of secondary metabolites (Modak et al., 2005), we conclude that HPLCDAD fingerprints of glandular trichomes can be used for fast and reliable detection as well as for the characterization of flavonoid patterns in members of Eupatorieae. In this report, the chemistry of the glandular trichomes of the two Chromolaena species revealed rich and diverse chemical species. Even if other flavonoids may be encountered in other parts of the leaves, the glandular trichomes are still a safe and reliable source to point special trends in accumulation of specific chemical subgroups and substitution patterns of these compounds, including glycosyl derivatives. 


\section{RESUMO}

Detecção de flavonóides nos tricomas glandulares de espécies de Chromolaena (Eupatorieae, Asteraceae), utilizando a cromatografia líquida de alta eficiência de fase reversa

Neste trabalho 12 flavonóides foram detectados nos tricomas glandulares de duas espécies de Chromolaena através do emprego da técnica de microamostragem de tricomas glandulares, associada à análise por CLAE. Esta é a primeira vez que se relata o acúmulo de flavonóides em tricomas glandulares no gênero. Com base nos resultados obtidos, podemos sugerir que esta técnica pode ser uma ferramenta útil na busca de substâncias com propriedades medicinais e em estudos quimiotaxonômicos de Eupatorieae.

UNITERMOS: Asteraceae. Chromolaena. Eupatorieae. Flavonoides. Tricomas glandulares. CLAE-DAD.

\section{AKNOWLEDGEMENTS}

The authors are grateful to FAPESP, CAPES and CNPq.

\section{REFERENCES}

CARVALHO, L.H.; BRANDÃO, M.G.; SANTOS-FILHO, D.; LOPES, J.L.; KRETTLI, A.U. Antimalarial activity of crude extracts from Brazilian plants studied in vivo in Plasmodium berghei-infected mice and in vivo against Plasmodium falciparum in culture. Braz. J. Med. Biol. Res., Ribeirão Preto, v.24, n.11, p.1113-1123, 1991.

DA COSTA, F.B.; SCHORR, K.; ARAKAWA, N.S.; SCHILLING, E.E.; SPRING, O. Infraspecific variation in the chemistry of glandular trichomes of two Brazilian Viguiera species (Heliantheae - Asteraceae). J. Braz. Chem. Soc., Campinas, v.12, n.3, p.403-407, 2001.

EMERENCIANO, V.P.; MILITÃO, J.S.L.T.; CAMPOS, C.C.; ROMOFF, P.; KAPLAN, M.A.C.; ZAMBON, M.; BRANT, A.J.C. Flavonoids as chemotaxonomic markers for Asteraceae. Biochem. Syst. Ecol., Oxford, v.29, n.9, p.947-957, 2001.

HERZ, W. Chemistry of the Eupatoriinae. Biochem. Syst. Ecol., Oxford, v.29, n.11, p.1115-1137, 2001.
MODAK, B.; CONTRERAS, L.; GONZÁLEZ-NILO, F.; TORRES, R. Structure-antioxidant activity relationships of flavonoids isolated from the resinous exudate of Heliotropium sinuatum. Bioorg. Med. Chem. Lett., New York, v.15, n.2, p.309-312, 2005.

OGUNDIPE, O.O.; MOODY, J.O.; HOUGHTON, P.J.; ODELOLA, H.A. Bioactive chemical constituents from Alchormea laxiflora (benth) pax and hoffman. J. Ethnopharmacol., London, v.74, n.3, p.275-280, 2001.

SCHORR, K.; GARCÍA-PINERES, A.J.; SIEDLE, B.; MERFORT, I.; DA COSTA, F.B. Guaianolides from Viguiera gardneri inhibit the transcription factor NF-kB. Phytochemistry, Oxford, v.60, n.7, p.733-740, 2002.

SPRING, O. Trichome microsampling of sesquiterpene lactones for the use of systematic studies, in: FISCHER, N.H., ISMAN, M.B., STAFFORD, A.H. (Eds.). Modern phytochemical methods. Recent advances in Phytochemistry. New York: Plenum Press, 1991. 319 p.

SPRING, O.; HEIL, N.; ELIASSON, U. Chemosystematic studies on the genus Scalesia (Asteraceae). Biochem. Syst. Ecol., Oxford, v.27, n.3, p.277-288, 1999.

SPRING, O. Chemotaxonomy based on metabolites from glandular trichomes. Adv. Bot. Res., London, v.31, p.153174, 2000.

SPRING, O.; ZIPPER, R.; REEB, S.; VOGLER, B.; DA COSTA, F.B. Sesquiterpene lactones and a myoinositol from glandular trichomes of Viguiera quinquerensis (Heliantheae-Asteraceae). Phytochemistry, Oxford, v.57, n.2, p.267-272, 2001.

SPRING, O.; ZIPPER, R.; CONRAD, J.; VOGLER, B.; KLAIBER, I.; DA COSTA, F.B. Sesquiterpene lactones from glandular trichomes of Viguiera radula (Heliantheae; Asteraceae). Phytochemistry, Oxford, v.62, n.8, p.1185-1189, 2003.

TALEB-CONTINI, S.H.; SALVADOR, M.J.; WATANABE, E.; ITO, I.Y.; OLIVEIRA, D.C.R. Antimicrobial activity of flavonoids and steroids isolated from two Chromolaena species. Rev. Bras. Cienc. Farm., São Paulo, v.39, n.4, p.403-408, 2003. 
TALEB-CONTINI, S.H.; SALVADOR, M.J.; BALANCO, J.M.F.; ALBUQUERQUE, S. OLIVEIRA, D.C.R. Antiprotozoal effect of crude extracts and flavonoids isolated from Chromolaena hirsuta (Asteraceae). Phytother. Res., London, v.18, n.3, p.250-254, 2004.

TALEB-CONTINI, S.H.; KANASHIRO, A.; KABEYA, L.M.; POLIZELLO, A.C.M.; LUCISANO-VALIM, Y.M.; OLIVEIRA, D.C.R. Immunomodulatory effects of methoxylated flavonoids from two Chromolaena species: structure-activity relationships. Phytother. Res., London, v.20, n.7, p.573-575, 2006.

URZÚA, A.; ANDRADE, L. Comparative chemical composition of the resinous exudates from Senecio adenotrichius and S. viscosissimus. Biochem. Syst. Ecol., Oxford, v.29, n.8, p.865-867, 2001.
WOLLENWEBER, E.; ROITMAN, J.N. A novel methyl ether of quercetagetin from Chromolaena odorata leaf exudate. Biochem. Syst. Ecol., Oxford, v.24, n.5, p.479480, 1996.

WOLLENWEBER, E.; DIETZ, V.H. Occurrence and distribution of free flavonoid aglycones in plants. Phytochemistry, Oxford, v.20, n.5, p.869-932, 1981.

XU, H.X.; LEE, S.F. Activity of plant flavonoids against antibiotic-resistant bacteria. Phytother. Res., London, v.15, n.1, p.39-43, 2001.

Recebido para publicação em 18 de abril de 2006. Aceito para publicação em 23 de março de 2007. 